\title{
Short Stories as a Genre of Literature to Teach Speaking Skills
}

\author{
Dr. R. Abilasha ${ }^{1, *}$, Dr. M. Ilankumaran ${ }^{2}$ \\ ${ }^{I}$ Assistant Professor of English, Noorul Islam Centre for Higher Education, Kumaracoil \\ ${ }^{2}$ Professor of English, Noorul Islam Centre for Higher Education, Kumaracoil
}

*Corresponding Author: Dr. R. Abilasha, Assistant Professor of English, Noorul Islam Centre for Higher Education, Kumaracoil, India

\begin{abstract}
The recent trend in teaching English as a Second Language is the necessity of integrating literature into language because of its richness in thought provoking ideas. Literature has many genres of which short stories seem to attract the learners in language acquisition. It enhances the four skills of language - listening, speaking, reading and writing - in general as the motivational factors are embedded in it. A close look at the way the language has come through centuries reveals that literature and language have not bonded so well that it can be used for learning a language. Many linguists like Collie J and Slater S (1987), Hall (2005) and Paran (2008) have recently supported the inclusion of literature in the language classroom as it plays a vital role in language acquisition. This paper focuses on the role of short stories as a tool to enhance speaking skills as a holistic approach as they can be taught within the allotted class time. Moreover, short stories have compact structures and the readability which instigate the readers become learners. The paper discusses how short stories pave ways to interact with the second language learners and enable them to perform better in the classroom. The teachers need to choose particular designs and techniques for teaching the selected short stores from their knowledge and experience.
\end{abstract}

Keywords: Language skills, Short stories, Literature, Reading skills, Activities

\section{INTRODUCTION}

When the Grammar Translation Method was in practice in the nineteenth century, translating literary texts from the target language to the native language was the major activity among others. The literary texts and works were the sources then in the classroom of the ESL. Ever since the GTM was replaced by Structuralism Approach in 1960s, the teaching of English was considered to be the matter of linguistics then and literature was not at all taken as a matter of importance or necessity when the Methods such as Direct Method, Audiolingualism, Community Language Teaching, Suggestopedia, the Silent Way, Total Physical Response and the Natural Approach almost till 1980s were active and successful in the ESL classroom. The literary works found no place in curriculum as they were 'unusable and impracticable' as the learners of the ESL aimed at communicating orally. In the beginning of 1980s, literature started finding its place in language classrooms as there was a radical change. The literary works, unless used in the GTM, are used to enhance the communicative skills by providing "a springboard for the development of critical thinking and aesthetic appreciation"(Bretz, 1990: 335-338). When the change in the curriculum took place, literature has started playing a significant role in language classroom. The use of literature in language classroom has many advantages. "Theoretically, using of literature in language classroom is very advantageous for it offers four benefits: authentic material, cultural enrichment, language advancement and personal growth" (Collie \& Slater, 1991).

\section{LiterATURE IN LANGUAGE TEACHING}

The literary texts give benefits to the learners than many so called informative materials. They stimulate the learners by exposing them to fresh and innovative themes with authenticated texts as a source. "The literary texts contain language intended for native speakers, literature stands as a model for language learners to become familiar with different forms and conventions."(Ur, 1996, p.201).These resources contain grammatical structures, real examples and vocabulary items and they are not written for any specific purpose particularly teaching. So they are rich and varied in language which encourages the learners to familiarize themselves with different language forms and uses. 
While learning a second language, culture is an important factor. Literature has the advantage of providing cultural information about the target language. "Literature texts increase foreign learners' insight into the country and the people whose language is being learnt" (Collie \&Slater,1991). Learners try to learn to see the things in literature through the eyes of another one. Learners of the ESL have the opportunity of understanding the social, political, historical and cultural events of the society they target at. Literature enables the learners to understand the culture, social ideologies of other societies which are completely different from their own so that they can have their personal growth and intellectual development.

The majority of the language classrooms are found isolated from the native language classrooms in the contexts of events and situations. Literature overcomes this problem because language can create its own context by using literary works. Thus, literature and its texts enable the learners to understand the language in a finer way with real experiences about the people, society and their relationship.

\section{SHORT STORIES AS A TOOL}

There are many genres in Literature and each of them plays a pivotal role in language classroom. Despite the uses are spoken or discussed, some objections are always there from some quarters. When poetry is taken, it takes a long time to grasp as it has many deviates and figurative usages. As far as novels are concerned, they are long and difficult to complete within the time. When drama is taken for teaching in a language classroom, it is difficult to act in a crowded classroom with the stipulated periods or hours allotted. Considering all these objections, among all the literary forms, short stories can be taken for teaching language in a classroom. Poe defines short stories "as a narrative that can be read at one sitting from one-half hour to two hours, and that is limited to 'a certain unique or single effect', to which every detail is subordinate"(Abrams, 1970, p. 158)

It is very obvious that short stories aim at providing single effect that is one plot with few characters and without any setting background. Hence, the learners find it easy to follow the story line. Moreover, they can be taught within the time allotted. The followings are the advantages of short stories.

- They are practical and long enough to complete in one or two classes.

- They are not complicated for the learners and they can work on themselves.

- They have a variety of choice for different interests and tastes.

- They can be taught to learners at all levels - beginners to advance learners.

Based on the points discussed, it is evident that short stories are suitable to teach in language classrooms.

\section{SELECTION OF A STORY}

The short story chosen should be aimed at encouraging learners to use the words they have already learned. It is the prime duty of the teacher to choose a right short story suitable to the learners' level and make it interesting with various teaching activities. The story needs to be short enough to complete in the limited class hours. On completion of practice, the learners have to feel achieved with self confidence. Three things have to be considered by the teacher while choosing a short story and they are a. the ability and capability of the learners, b. the vocabulary and structure of the language in the text and c. the background information to be provided to the learners. The teachers should avoid the short stories with archaic, slang, foreign words and allusions. Similarly the short stories with very long sentences and difficult words should also be avoided at the beginning level of teaching. Interesting short stories are always preferred. According to Ur (1996), "...the use of authentic text with less proficient learners is often frustrating and counter-productive" (p.150)

\section{ENHANCEMENT OF SPEAKIng SKILlS THROUgh SHORT STORIES}

Though short stories can be used for teaching the four skills at all levels in a language classroom, the bottom line is fixed at speaking skills. The prime duty of a teacher is to know how well a short story can be used in a language classroom. The followings are some of the activities a teacher can assign to the learners. 
- The learners have to read the lines of the story aloud as a chain activity. When the first two sentences are read by a learner, the second one has to continue reading the next lines and it has to go on. This activity will enhance the learners' skills on reading with pronunciation and fluency of using words.

- In the second stage, the teachers have to ask the learners to retell the stories as a chain activity after it is given a wide reading. All the students should have the chance and teacher has to enable them to coherent the sentences by giving them the connectors and discourse markers.

- In the next stage, the learners must be grouped into two. The two groups should prepare points to argue for and against the main concept of the story.

- In an advanced stage, role play of the characters can be played with the sentences made into dialogues (as screen play is done in celluloid field). An interesting and impressive act can be rewarded to motivate the slow learners.

\section{CONCLUSION}

The objective of taking short stories to teach English as a language is to make the learners communicate fluently. As the learners are very much lay as for as language is concerned, the teachers have to take a lead role by providing them with an authentic model of language use. The most important factor to be considered in teaching short stories is the selection of stories that should be in reference to the level of grasping ability of the learners, story content and the objective of the course. It is evident to point out here that every teaching situation is unique from one classroom to another; the calibre of learner is different from one to another and the teaching technique and pattern may differ from one teacher to another. Short stories create a meaningful context to teach different language styles and to enhance the interpretative strategies of learners. To top to all, short stories help learners develop their vocabulary also.

\section{REFERENCES}

[1] Abrams, M. H. A Glossary of Literary Terms. New York: Rinehart. 1970. Print. Bretz, M. L. Reaction: Literature and Communicative Competence: A Springboard for the Development of Critical Thinking and Aesthetic Appreciation. Foreign Language Annals, 23(4), 335-338. 1990. Print.

[2] Carter, R., \&Long, M. N. Teaching Literature. Harlow: Longman. 1991.Print.

[3] Collie, J., \& Slater, S. Literature in Language Classroom. ( $5^{\text {th }}$ ed.). Glasgow: Cambridge University Press, 1991.Print.

[4] Ur, P. A Course in Language Teaching: Practice and Theory, Cambridge: Cambridge University Press, 1996.Print.

Citation: Dr. R. Abilasha, Dr. M. Ilankumaran, "Short Stories as a Genre of Literature to Teach Speaking Skills" International Journal on Studies in English Language and Literature (IJSELL), vol 6, no. 1, 2018 , pp. 25-27. doi:http://dx.doi.org/10.20431/2347-3134.0601004.

Copyright: (C) 2018 Authors. This is an open-access article distributed under the terms of the Creative Commons Attribution License, which permits unrestricted use, distribution, and reproduction in any medium, provided the original author and source are credited. 